\title{
Tolerability, pharmacokinetics and pharmacodynamics of CMAB001, an anti-CD11a antibody, in Chinese healthy volunteers and psoriatic patients
}

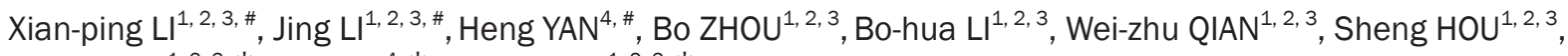 \\ Hao WANG ${ }^{1,2,3, *}$, Fei $\mathrm{HAO}^{4, *}$, Ya-jun $\mathrm{GUO}^{1,2,3, *}$ \\ ${ }^{1}$ International Cancer Research Institute, Second Military Medical University, Shanghai 200433, China; ${ }^{2}$ National Engineering \\ Research Center of Antibody Medicine, Shanghai 201203, China; ${ }^{3}$ PLA General Hospital Cancer Center, PLA Postgraduate School of \\ Medicine, Beijing 100853, China; ${ }^{4}$ Xi-nan Hospital, Third Military Medical University, Chongqing 400038, China
}

\begin{abstract}
Aim: To evaluate the pharmacokinetics (PK), pharmacodynamics (PD) and primary tolerability of an anti-CD11a monoclonal antibody (CMAB001) in Chinese healthy volunteers and psoriatic patients.

Methods: Two open-label studies were conducted. One was a parallel-group, single-center, dose-escalation test, including 24 healthy adult volunteers from 18 to 45 years in age. All subjects randomly received a single subcutaneous injection dose of $0.5,1.0$, or 2.0 $\mathrm{mg} / \mathrm{kg}$. The other was a multiple-dose study: 10 adult psoriatic patients were administered weekly subcutaneous injections of 1.0 $\mathrm{mg} / \mathrm{kg}$ for 7 weeks.

Results: CMAB001 was well tolerated in the single- and multiple-dose studies. Slow absorption was observed in both studies. In the single-dose study, the concentration of CMAB001 reached its highest level $2 \mathrm{~d}$ later after the injection, and the $C_{\max }$ increased in an approximate dose-proportionate manner, while the area under curve (AUC) showed much greater than dose-proportionate increase. In the multiple-dose study, the steady-state serum concentration level was attained following the 4th injection.

Conclusion: CMAB001 exhibited a nonlinear pharmacokinetic profile over the dose range from 0.5 to $2.0 \mathrm{mg} / \mathrm{kg}$, and was well tolerated in healthy volunteers and psoriatic patients.
\end{abstract}

Keywords: chronic plaque psoriasis; CD11a; humanized antibody; CMAB001; pharmacokinetics; pharmacodynamics; tolerability; openlabel study

Acta Pharmacologica Sinica (2012) 33: 1085-1094; doi: 10.1038/aps.2012.65; published online 16 Jul 2012

\section{Introduction}

Psoriasis, a common skin disease, is an autoimmune disorder of the dermis and epidermis characterized by leukocyte infiltration into the skin and localized deregulated skin growth. Clinical manifestations in patients with this disease include white or silver scaly and raised plaques that are either red or salmon pink in color ${ }^{[1]}$. Although the precise cause of psoriasis remains an enigma, it has become increasingly clear that the activity of the lymphocytic infiltration, which consists primarily of $\mathrm{T}$ cells, is the driving force for the induction of the skin

\footnotetext{
"These authors contributed equally to this work.

* To whom correspondence should be addressed.

E-mail yjguo@smmu.edu.cn (Ya-jun GUO); haofei@mail.tmmu.com.cn (Fei HAO); hwang_smmu@163.com (Hao WANG). Received 2012-01-18 Accepted 2012-05-09
}

changes observed in psoriasis and is also required for maintenance of the plaques ${ }^{[1,2]}$.

Currently, a class of therapeutics, the "biologics", has shown promise by specifically interfering with the T-lymphocytemediated immune responses that are characteristic of psoriasis and other autoimmune diseases ${ }^{[2-9]}$. CD11a-specific mAb is a typical biotherapeutic product. T-lymphocyte activation and infiltration into tissues is mediated by events involving the specific interaction between a T-cell receptor and the major histocompatibility complex on antigen-presenting cells (APCs). Full activation of T lymphocytes, however, occurs only after other T-cell surface molecules engage with the APC. This costimulatory process involves the interaction between lymphocyte function-associated antigen-1 (LFA-1) and intercellular adhesion molecule-1 (ICAM-1). LFA-1 is an adhesion molecule expressed in leukocytes and is character- 
ized by heterodimers with a common $\beta$ chain (CD18) and a unique a chain (CD11a). The LFA-1: ICAM-1 interaction is a key element in stabilizing the immunologic synapse that forms between T cells and APCs and also mediates the binding of T cells to endothelial cells ${ }^{[2,10,11]}$. Blocking the costimulatory signaling process and inhibiting the interaction of these ligands pairs have been shown to be effective in the treatment of autoimmune diseases, such as psoriasis ${ }^{[4,7,12]}$.

Efalizumab (Raptiva ${ }^{\circledR}$ ) is a recombinant, humanized CD11aspecific $\mathrm{mAb}$ developed by Genentech Inc that can bind to CD11a, preventing LFA-1 binding to ICAM- ${ }^{[6]}$. The restricted expression of CD11a limits the potential effects of efalizumab to cells that express LFA- ${ }^{[13]}$. Since its approval in the United States in 2003, efalizumab has proven efficacious in the treatment of psoriasis. However, four cases of the rare neurological condition progressive multifocal leukoencephalopathy (PML) were reported in plaque psoriasis patients treated with efalizumab. Subsequently, in April 2009, efalizumab was withdrawn from the market by its manufacturer.

CMAB001 is a novel recombinant humanized CD11a-specific $\mathrm{mAb}$ that recognizes a different epitope than efalizumab. CMAB001 was developed by the National Engineering Research Center of Antibody Medicine (NERCAM) in China and is an IgG1 kappa immunoglobulin that contains human constant region sequences and murine light- and heavy-chain complementary determining region sequences. In this study, our aim is to explore the PK, PD and primary safety profiles of single/multiple doses of CMAB001 in healthy volunteers and psoriatic patients.

\section{Materials and methods Drug nomenclature}

CMAB001 is a novel recombinant humanized CD11a-specific $\mathrm{mAb}$ developed by NERCAM in China. CMAB001 is directed against a different epitope than efalizumab and is an IgG1 kappa immunoglobulin that contains human constant region sequences and murine light- and heavy-chain complementary determining region sequences. The apparent molecular weight of this mAb is $150 \mathrm{kDa}$ and is constructed based on DNA-recombination technology, produced as a secreted protein in a Chinese hamster ovary mammalian cell expression system, purified and formulated as a pharmaceutical-grade product. The reagent contains $80 \mathrm{mg}$ active component, 16 $\mathrm{mg}$ sucrose, $4.53 \mathrm{mg}$ L-histidine hydrochloride, $2.87 \mathrm{mg}$ L-histamine, and $2.0 \mathrm{mg}$ polysorbate per vial, supplied as a sterile, white-to-off-white, preservative-free, lyophilized powder for subcutaneous (sc) administration, following reconstitution with $1 \mathrm{~mL}$ of sterile water.

\section{Study design and subjects}

In animal studies, the highest dose tested was $50 \mathrm{mg} / \mathrm{kg}$ in experimental monkeys. According to FDA and EMEA guidelines on maximum safe starting doses in healthy volunteers, this value was divided by 6.2 to obtain the human-equivalent dose and then further divided by 15 , the safety factor, to arrive at a dose of $0.5 \mathrm{mg} / \mathrm{kg}$. Additional doses were calculated based on an escalation factor of approximately two. At the same time, we performed the efalizumab trials as a reference.

This study was conducted according to the ethical principles of the revised Declaration of Helsinki and Good Clinical Practice (GCP) requirements. The study protocol was approved by the identifiable ethics committee of the First Affiliated Hospital of the Third Military Medical University and the State Food and Drug Administration of China (SFDA). The approval number of SFDA was 2005L03600. The subjects consented to the study after a full explanation of what was involved, and signed informed consent forms prior to participation.

Part one was a single-dose, dose-escalation study. Twentyfour eligible, healthy, adult volunteers were randomly divided into three groups to receive a single subcutaneous injection with a dosage of $0.5,1.0$, or $2.0 \mathrm{mg} / \mathrm{kg}$ after consuming a standardized breakfast. The ages of these volunteers varied from 18 to 45 years; their weights were within normal limits; clinical laboratory values, ECG, and chest $\mathrm{X}$-rays were within the normal ranges $7 \mathrm{~d}$ before medication. Each subject entered the study unit the day before administration, received CMAB001, was discharged temporarily after $24 \mathrm{~h}$ of observation and was then required to return to the ward for blood sample collection and a trial-related physical examination.

Part two was conducted in psoriatic patients: 10 patients were assigned to receive subcutaneous injection and were dosed with $1.0 \mathrm{mg} / \mathrm{kg}$ weekly for 7 weeks. Enrolled patients were aged 18 to 65 years, and each had a moderate-to-severe, chronic, stable condition lasting more than 6 months, body surface involvement $\geq 10 \%$, PASI $\geq 12$. After each injection, the patients were observed following a consistent amount of time. Concomitant medication was prohibited during the entire study period.

Major exclusion criteria included suspected or documented severe infection, such as erysipelas or nephritis; having received any other test drug within 3 months before medication; history of donating blood within 3 months; abnormal ECG and chest X-ray test; transaminase levels 1.5 times higher than the upper normal limit; severe concomitant disease or complications in the kidneys, heart, lung, and blood system or a malignant tumor or family history of cancer. Women had to receive a negative pregnancy test before medication. During the entire study duration, women and men had to agree to the use of contraception.

\section{Sample collection for pharmacokinetics}

In part one, blood samples for the determination of drug concentration were taken from the radial vein before administration of the drug and $0.5,4,12,24$, and $36 \mathrm{~h}$ after the injection. Blood samples were also drawn 2, 3, 5, 7, 9, 11, 14, 21, 28, 35, and $49 \mathrm{~d}$ after the injection. In part two, blood samples for drug concentration detection were obtained before each injection and within $48 \mathrm{~h}$ after the fourth, fifth, and sixth injections. Other blood samples were collected 1, 3, 5, 9, 14, 28, and $42 \mathrm{~d}$ after the last injection. For each sample, serum was harvested by centrifugation from $3 \mathrm{~mL}$ of whole blood and stored for analysis at $-20^{\circ} \mathrm{C}$. Blood samples were also obtained from 
subjects during their routine clinic visit for full blood count and biochemistry tests.

\section{Sample collection for monitoring lymphocyte subsets}

Blood samples were collected in tubes containing sodium citrate before administration as well as 2, 7, 28, and $49 \mathrm{~d}$ after the injection in part one of the study; and before the first injection and on $\mathrm{d} 14,28,42,56$, and 84 after the first dose (but before each injection) in part two of the study.

\section{Anti-antibody and neutralizing anti-antibody antibody}

Serum samples were drawn before injection, 14 and $49 \mathrm{~d}$ after injection in part one; before the first injection, $d 7,14,21,56$, and 84 after the first dose (but before each injection) in part two, for detection of anti-CMAB001 antibodies using antibody-bridge methods.

\section{CMAB001 serum concentration level assay}

A cell-based competitive flow cytometric (C-FCM) assay was developed to determine the serum concentration of CMAB001. We chose KG-1a, a cell line expressing CD11a, as target cells. The target cells were coated with FITC-labeled-CMAB001, and these labeled CMAB001 could compete with unlabelled CMAB001 in the test samples. The FITC-labeled CMAB001 and a series of calibration standards were provided by NERCAM. The standard test protocol is summarized below: KG-1a cells were harvested from culture by centrifugation and resuspended in wash buffer (PBS buffer with $1 \%$ new bovine serum, PBSS) to give approximately $1 \times 10^{6}$ cells $/ \mathrm{mL}$. One hundred microliters of FITC-labeled-CMAB001 $(2 \mu \mathrm{g} / \mathrm{mL})$ and a series of calibration standards (or the test samples) were mixed with a $100-\mu \mathrm{L}$ cell suspension in a sample tube, and then, the mixture was incubated on ice for $45 \mathrm{~min}$. Wash buffer was added, and the cells were pelleted by centrifugation at $200 \times g$ for $5 \mathrm{~min}$, and then, the supernatants were removed. This procedure was repeated three times, and then, the cells were resuspended in $300 \mu \mathrm{L}$ of PBSS. Finally, the cells were analyzed on a FACScan (BD, NJ, USA). All serum samples were diluted and run in duplicate. Calibration standards and quality control (QC) samples were run three times. The standard curve was established using the four-parameter logistic equation: $Y=\left(A_{1}-A_{2} /\left[1+\left(X / X_{0}\right)^{\mathrm{P}}\right]+A_{2}\right.$. $Y$ represents the fluorescence intensity of the sample; $X$ represents the concentration of CMAB001; $A_{1}$ and $A_{2}$ represent the maximal and the minimal fluorescence intensity, respectively; $X_{0}$ represents half of the maximal effective concentration and $P$ represents the slope of the logit-log plot. The calculated value of each sample was required to be within the range of the standard curve.

\section{T lymphocyte subset monitoring assay}

Psoriasis is a T cell mediated immune disorder in which $\mathrm{CD}^{+}$, $\mathrm{CD}^{+}$, and $\mathrm{CD}^{+}$memory $\mathrm{T}$ cells stimulate the hyperproliferation of keratinocytes. Thus, we selected $\mathrm{CD}^{+}, \mathrm{CD}^{+}$, and $\mathrm{CD}^{+}$ $\mathrm{T}$ cells as pharmacodynamic markers to investigate the influence of CMAB001 on circulating lymphocytes. Circulating peripheral blood $\mathrm{T}$ cells were monitored by flow cytometric analysis. MAbs used for immunophenotyping included the following (all purchased from Becton Dickinson): mouse anti human CD3-FITC (IgG1); mouse anti human CD3-PC (IgG1); mouse anti human CD4-FITC (IgG1) and mouse anti human CD8-PE (IgG1). FITC/dimethyl formamide was added to purified $\mathrm{mAb}$ at $1: 10$ weight/weight and incubated at $25^{\circ} \mathrm{C}$ for $4 \mathrm{~h}$, followed by dialysis into phosphate-buffered saline containing an anion exchange resin (AG1-X8, 200-400 mesh, chloride form, Bio-Rad, New York, NY, USA). Aggregates were removed by centrifugation. Staining of peripheral blood lymphocytes (PBL) with fluorochrome-labeled $\mathrm{mAb}$ was performed in whole blood and analyzed on a FACScan flow cytometer (Becton Dickinson Immunocytometry Systems, San Jose, CA, USA).

\section{Enzyme-linked immunoabsorbent assay for anti-CMAB001 antibody}

Serum anti-CMAB001 antibody formation was monitored using a double-antigen enzyme-linked immunoabsorbent assay (ELISA). CMAB001 was used as the solid-phase capture reagent, and binding of anti-CMAB001 antibodies to the coated and blocked wells was detected using an HRPconjugated CMAB001 antibody. Colorimetric measurement and data analysis were performed with an ELISA plate reader. Regression of sample optical densities from a calibration curve using rabbit anti-CMAB001 antibodies results in a quantitative range of approximately 160 to $20000 \mathrm{ng} / \mathrm{mL}$ anti-CMAB001 idiotype equivalents. When the samples were positive, neutralizing anti-antibody antibody would subsequently be detected by the above cell-based competitive flow cytometric assay.

\section{Validity of the method for determination}

A specificity test of the assay demonstrated that $0.5 \mu \mathrm{g} / \mathrm{mL}$ human serum would not interfere with CMAB001 quantification. Proteins, such as human immunoglobulin, globulin and anti-CD25 monoclonal antibody, did not interfere with the determination of CMAB001 serum concentration. The recovery rates of blank serum fortified with $0.02,0.5$, and $12.5 \mu \mathrm{g} / \mathrm{mL}$ were $0.020 \% \pm 0.002 \%, 0.498 \% \pm 0.020 \%$, and $11.529 \% \pm 1.536 \%$, respectively. The range of serum concentration quantification was $0.02-12.5 \mu \mathrm{g} / \mathrm{mL}$. The limitation of quantification (LOQ) of the assay was demonstrated to be $0.02 \mu \mathrm{g} / \mathrm{mL}$. The pass/ fail criteria for the assay were determined by the performance of QC in each assay. The results were acceptable if the ratio of (detected concentration)/(QC sample concentration) was between $75 \%$ and $125 \%$ and the bias of (detected concentration-QC sample concentration)/(QC sample concentration) was between $-20 \%$ and $20 \%$. The validity of the method demonstrated that the C-FCM assay was reliable for the determination of serum levels. The specificity, sensitivity, accuracy, and precision met the requirements for the study of PK and PD.

\section{Statistical analysis}

Statistical analysis was performed with SPSS 13.0 software for Windows operating system (SPSS Inc, Chicago, IL, USA). All 
grouped data were expressed as the mean \pm standard deviation (SD). For the comparison of the data among at least three groups, analysis of variance (ANOVA) was applied to test the differences in the data on a normal distribution, and the Kruskal-Wallis test (K-W H test) was used when data were not normally distributed. For a difference between the two groups, the $t$-test was employed when the data were of normal distribution and when the variance was homogenous; otherwise, the Wilcoxon test was used. A $P$ value $<0.05$ was considered statistically significant.

\section{Data analysis}

The PK parameters in the single-dose study included the following: area under the concentration-time curve (AUC); AUC from 0 to last time point $\left(\mathrm{AUC}_{0-\mathrm{z}}\right)$, $\mathrm{AUC}$ from 0 to infinity $\left(\mathrm{AUC}_{0-\infty}\right)$, maximum serum concentration $\left(C_{\max }\right)$, dosenormalized AUC (AUC/D), dose-normalized $C_{\max }\left(C_{\max } / \mathrm{D}\right)$, time to $C_{\max }\left(T_{\max }\right)$, half-life $\left(t_{1 / 2}\right)$, clearance rate $(\mathrm{Cl})$ and distribution volume $\left(V_{\mathrm{d}}\right)$. The pharmacokinetic parameters in part two also included the AUC in steady state $\left(\mathrm{AUC}_{\mathrm{ss}}\right)$, clearance rate in steady state $\left(\mathrm{Cl}_{\mathrm{ss}}\right)$, distribution volume in steady state $\left(V_{\mathrm{ss}}\right)$, maximum steady-state concentration $\left(C_{\max s s}\right)$, minimum steady-state concentration $\left(C_{\operatorname{minss}}\right)$ and the average steadystate concentration $\left(C_{\text {avg }}\right)$. The individual PK parameters were calculated by WinNonLin ${ }^{\circledR}$ statistics software (Pharsight Corporation, USA) using non-compartment methods of analysis. AUC was calculated using the linear-up/log-down approach. $C_{\max }$ and $T_{\max }$ were defined as observed.

\section{Results}

\section{Demographics}

In part one, volunteers were college students, aged 22.8 \pm 1.4 , $22.1 \pm 1.6$, and $22.1 \pm 1.5$ years, respectively. The three groups were well matched with respect to demographic characteristics. All of the groups remained at the hospital study unit for $24 \mathrm{~h}$ after each injection. In part two, the ten patients (five men, five women) were between 18 and 65 years in age (Table 1).

\section{Single-dose pharmacokinetics of CMAB001 in healthy volunteers} No blood samples were missed in part one. The mean $( \pm S D)$ serum concentration-time curves of CMAB001 following a dose of $0.5,1.0$, and $2.0 \mathrm{mg} / \mathrm{kg}$ are shown in Figure 1. Pharmacokinetic parameters were observed by non-compartmental analysis (Table 2). The data indicated that the drug concentration reached its peak level two days after injection. $T_{\max }$

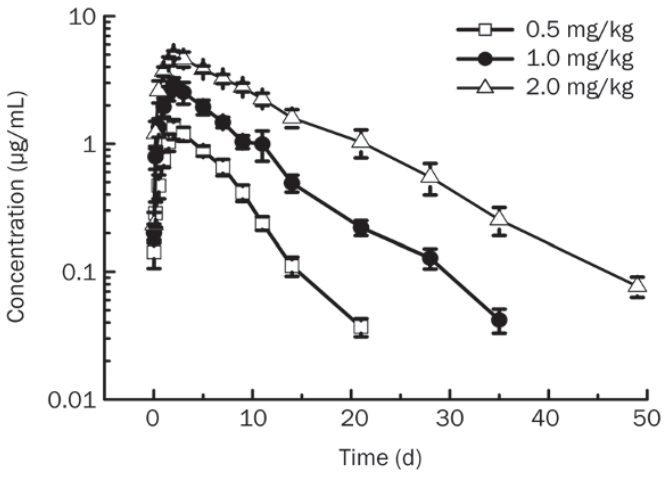

Figure 1. Logarithmic mean concentration-time curves of CMAB001 in healthy volunteers after a single subcutaneous infusion of $0.5 \mathrm{mg} / \mathrm{kg}$. Data are expressed as the mean \pm SD. $n=8$.

ranged from 2.1 to $3.3 \mathrm{~d}$ among the three groups. The mean ( \pm SD) $C_{\max }$ was $1.348 \pm 0.222 \mu \mathrm{g} / \mathrm{mL}, 3.006 \pm 0.402 \mu \mathrm{g} / \mathrm{mL}$, and $5.128 \pm 0.467 \mu \mathrm{g} / \mathrm{mL}$ in the $0.5,1.0$, and $2.0 \mathrm{mg} / \mathrm{kg}$ dose groups, respectively. Concentrations slowly decreased with $t_{1 / 2}$ at $3.49 \pm 0.31 \mathrm{~d}, 5.81 \pm 0.41 \mathrm{~d}$, and $7.55 \pm 0.81 \mathrm{~d}$, respectively. MRT and $t_{1 / 2}$ showed the same tendency. $\mathrm{Cl}$ decreased from approximately 54.9 to $31.7 \mathrm{~mL}^{-1} \cdot \mathrm{d}^{-1} \cdot \mathrm{kg}^{-1}$ among the three groups. Dose-normalized $C_{\max }\left(C_{\max } / \mathrm{D}\right)$ was $2.295 \pm 0.444$ $\mathrm{d} \cdot \mathrm{kg} \cdot \mathrm{L}^{-1}, 3.006 \pm 0.402 \mathrm{~d} \cdot \mathrm{kg} \cdot \mathrm{L}^{-1}$, and $2.564 \pm 0.233 \mathrm{~d} \cdot \mathrm{kg} \cdot \mathrm{L}^{-1}$ in the 0.5, 1.0 , and $2.0 \mathrm{mg} / \mathrm{kg}$ dose groups, respectively. Dose-normalized $\mathrm{AUC}_{0-\mathrm{z}}$ showed more than a dose-proportional increase. Taken together, these results indicated that CMAB001 exhibited a nonlinear pharmacokinetic profile over the dose range of $0.5-2.0 \mathrm{mg} / \mathrm{kg}$ in healthy volunteers. A significant difference was observed in parameter dose-normalized $\mathrm{AUC}_{0-\mathrm{z}}, \mathrm{Cl}$, $C_{\max }, \mathrm{MRT}$, and $t_{1 / 2}$ among the three groups $(P<0.001, \mathrm{~K}-\mathrm{W}$ $\mathrm{H}$ test). A dose-proportional increase of $C_{\max }$ was observed; $\mathrm{AUC}_{0-\mathrm{z}}, t_{1 / 2}$, and $\mathrm{Cl}$ showed non-linear pharmacokinetic profiles (Figure 2).

\section{Lymphocyte subset proportion in single-dose groups}

We measured proportions of $\mathrm{CD}^{+}, \mathrm{CD}^{+}$, and $\mathrm{CD}^{+} \mathrm{T}$ cell subsets using FCM before and after CMAB001 injection. The most rapid increases in $\mathrm{CD}^{+}, \mathrm{CD}^{+}$, and $\mathrm{CD}^{+} \mathrm{T}$ cells levels were observed $7 \mathrm{~d}$ after the administration of CMAB001 in the three single-dose groups (Figure 3). The increase in $\mathrm{CD}^{+} \mathrm{T}$ cells showed statistical significance compared with baseline level in all three groups, while there was not a statistically significant difference found in the $2.0 \mathrm{mg} / \mathrm{kg}$ group for $\mathrm{CD} 4^{+}$

Table 1. Demographic characteristics of subjects enrolled in single- and multiple-dose studies. Values were shown as mean $\pm S D$ (range).

\begin{tabular}{lcccc}
\hline & & Single-dose (part one) & Multiple-dose (part two $)$ \\
$1.0 \mathrm{mg} / \mathrm{kg}(n=10)$ & $1.0 \mathrm{mg} / \mathrm{kg}(n=8)$ & $2.0 \mathrm{mg} / \mathrm{kg}(n=8)$ & $22.1 \pm 1.5(20-24)$ & $35.5 \pm 1.4(19-48)$ \\
Age (years) & $0.5 \mathrm{mg} / \mathrm{kg}(n=8)$ & $22.1 \pm 1.6(20-24)$ & 0 female, 8 male & 5 female, 5 male \\
Sex & $22.8 \pm 1.4(20-24)$ & 0 female, 8 male & $167.6 \pm 5.9(165-174)$ & $166.4 \pm 2.9(163-171)$ \\
Height $(\mathrm{cm})$ & 0 female, 8 male & $166.9 \pm 5.4(165-172)$ & $58.2 \pm 3.5(55-70)$ & $61.2 \pm 3.9(58-71)$ \\
Weight (kg) & $168.3 \pm 5.5(166-171)$ & $59.6 \pm 5.0(56-69)$ & & \\
\hline
\end{tabular}


Table 2. Pharmacokinetic parameters after a single-dose subcutaneous injection in healthy volunteers. AUC $\mathrm{C}_{0-z}$, area under the concentration-time curve from 0 to the last time point; $A U C_{0-\infty}$, area under the concentration-time curve from 0 to infinity; MRT, mean retention time. $C_{\text {max }} / D$, dose-normalized $C_{\text {max }} ; \mathrm{AUC}_{0-z} / \mathrm{D}$, dose-normalized $\mathrm{AUC}_{0-\mathrm{z}}$. Data were expressed as mean \pm SD. $n=8 .{ }^{\mathrm{C}} P \leq 0.001 \mathrm{vs} 0.5 \mathrm{mg} / \mathrm{kg}$. ${ }^{\mathrm{f}} P \leq 0.001 \mathrm{vs} 2.0 \mathrm{mg} / \mathrm{kg}$ (Student's $t$-test).

\begin{tabular}{|c|c|c|c|c|}
\hline Parameters & $0.5 \mathrm{mg} / \mathrm{kg}$ & $1.0 \mathrm{mg} / \mathrm{kg}$ & $2.0 \mathrm{mg} / \mathrm{kg}$ & $P$ \\
\hline $\mathrm{AUC}_{(0-z)}\left(\mathrm{d} \cdot \mu \mathrm{g} \cdot \mathrm{mL}^{-1}\right)$ & $8.99 \pm 0.82$ & $24.97 \pm 2.27^{\mathrm{cf}}$ & $62.78 \pm 6.25^{c}$ & $<0.001$ (K W H-test) \\
\hline $\mathrm{Cl}\left(\mathrm{mL}^{-1} \cdot \mathrm{d}^{-1} \cdot \mathrm{kg}^{-1}\right)$ & $54.9 \pm 5.1$ & $39.8 \pm 3.5^{\mathrm{cf}}$ & $31.7 \pm 3.0^{c}$ & $<0.001$ (K W H-test) \\
\hline$V_{\mathrm{d}}\left(\mathrm{mL} \cdot \mathrm{kg}^{-1}\right)$ & $277.0 \pm 41.0$ & $333.0 \pm 39.0$ & $347.0 \pm 64.0$ & 0.026 (ANOVA) \\
\hline$t_{1 / 2}(\mathrm{~d})$ & $3.49 \pm 0.31$ & $5.81 \pm 0.41^{\mathrm{cf}}$ & $7.55 \pm 0.81^{c}$ & $<0.001$ (K W H-test) \\
\hline MRT (d) & $6.09 \pm 0.32$ & $8.03 \pm 0.66^{\mathrm{cf}}$ & $12.02 \pm 0.82^{c}$ & 0.001 (ANOVA) \\
\hline$T_{\max }(\mathrm{d})$ & $2.13 \pm 0.35$ & $3.25 \pm 3.15$ & $2.13 \pm 0.35$ & 1.000 (ANOVA) \\
\hline
\end{tabular}
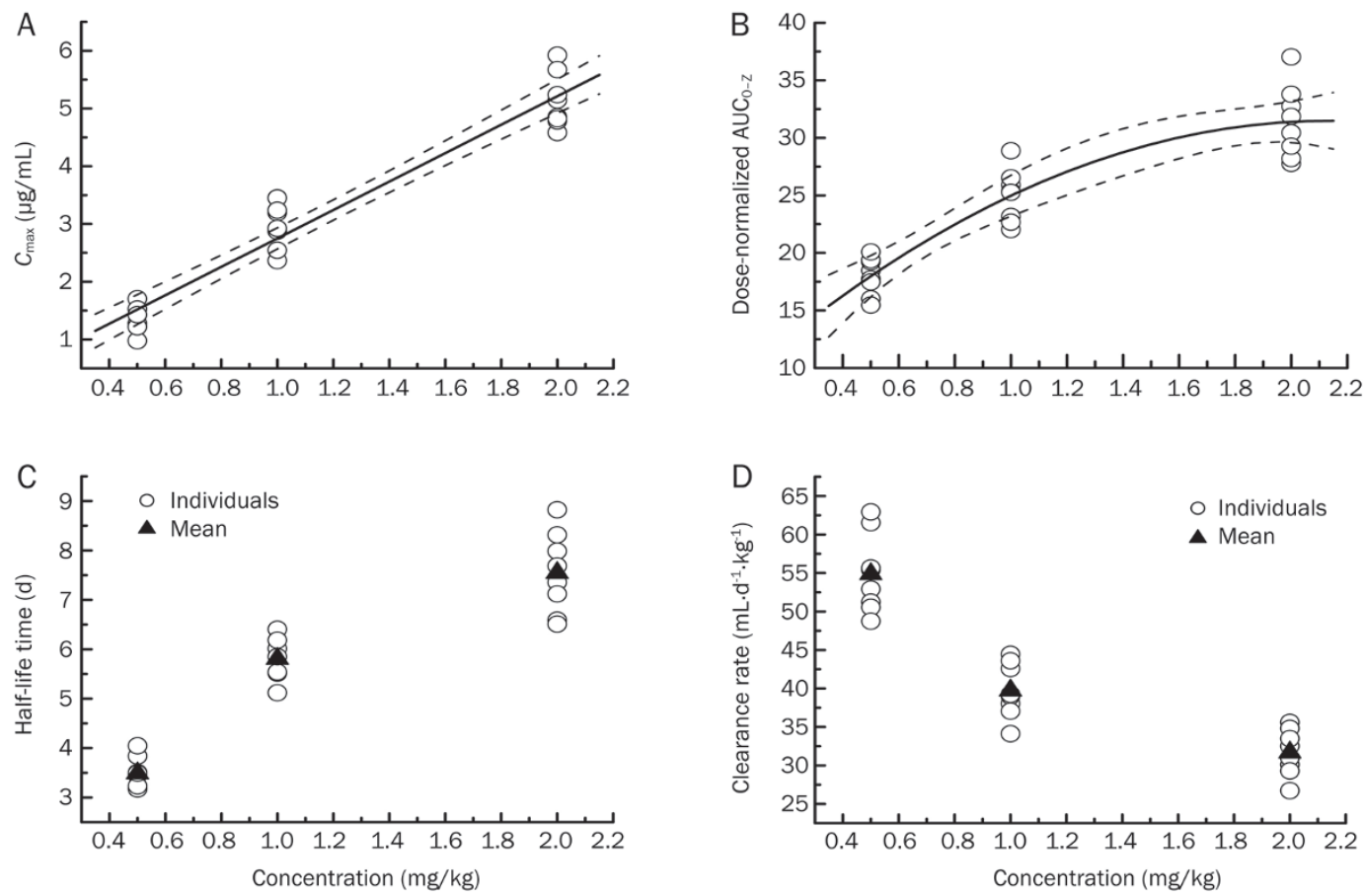

Figure 2. Linear regression analyses of $C_{\max }(\mathrm{A})$, polynomial regression analyses of dose-normalized $\mathrm{AUC}_{0-\mathrm{z}}(\mathrm{B})$, graphical display scatter chart of $T_{1 / 2}(\mathrm{C})$ and $\mathrm{Cl}(\mathrm{D})$ as a function of CMAB001 over the range of $0.5-2.0 \mathrm{mg} / \mathrm{kg}$ in the single-dose groups. Dashed lines in $2 \mathrm{~A}$ and $2 \mathrm{~B}$ represent $95 \% \mathrm{Cl}$.

$\mathrm{T}$ cells. For $\mathrm{CD} 8^{+} \mathrm{T}$ cells, a statistically significant difference in increase was found only in the $0.5 \mathrm{mg} / \mathrm{kg}$ group. For $\mathrm{CD}^{+} \mathrm{T}$ cells, the highest increase from the baseline level was observed in the $0.5 \mathrm{mg} / \mathrm{kg}$ group (Figure 3D). Increases in the absolute counts of circulating lymphocytes and white blood cells (WBC) were also observed following single-dose injections (Figure 4). Lymphocyte absolute counts increased more than $50 \%$ from baseline seven days after injection in all three groups (Figure 4B). We observed that the greatest increase in absolute lymphocyte count was $81.3 \%$ in the $1.0 \mathrm{mg} / \mathrm{kg}$ group, and the increases were $76.5 \%$ and $52.9 \%$ in the 0.5 and $2.0 \mathrm{mg} / \mathrm{kg}$ groups, respectively. The increase in absolute lymphocyte count among the three groups was significantly dif- ferent $(P<0.01$ in the 0.5 and $1.0 \mathrm{mg} / \mathrm{kg}$ groups, $P<0.05$ in the $2.0 \mathrm{mg} / \mathrm{kg}$ group. Paired $t$-test). The largest increase in white blood cell count also occurred in the $1.0 \mathrm{mg} / \mathrm{kg}$ group (Figure $4 \mathrm{D}, P<0.01$. Paired $t$-test).

\section{Multiple-dose pharmacokinetics of CMAB001 in psoriatic patients}

In this part of the study, 150 blood samples were collected for pharmacokinetic analysis. The mean $( \pm S D)$ serum concentration-time curves of CMAB001 following multiple subcutaneous injection with a dose of $1.0 \mathrm{mg} / \mathrm{kg}$ are shown in Figure 5 . The pharmacokinetics parameters are summarized in Table 3 and Table 4 . The analysis showed that the steady-state serum 

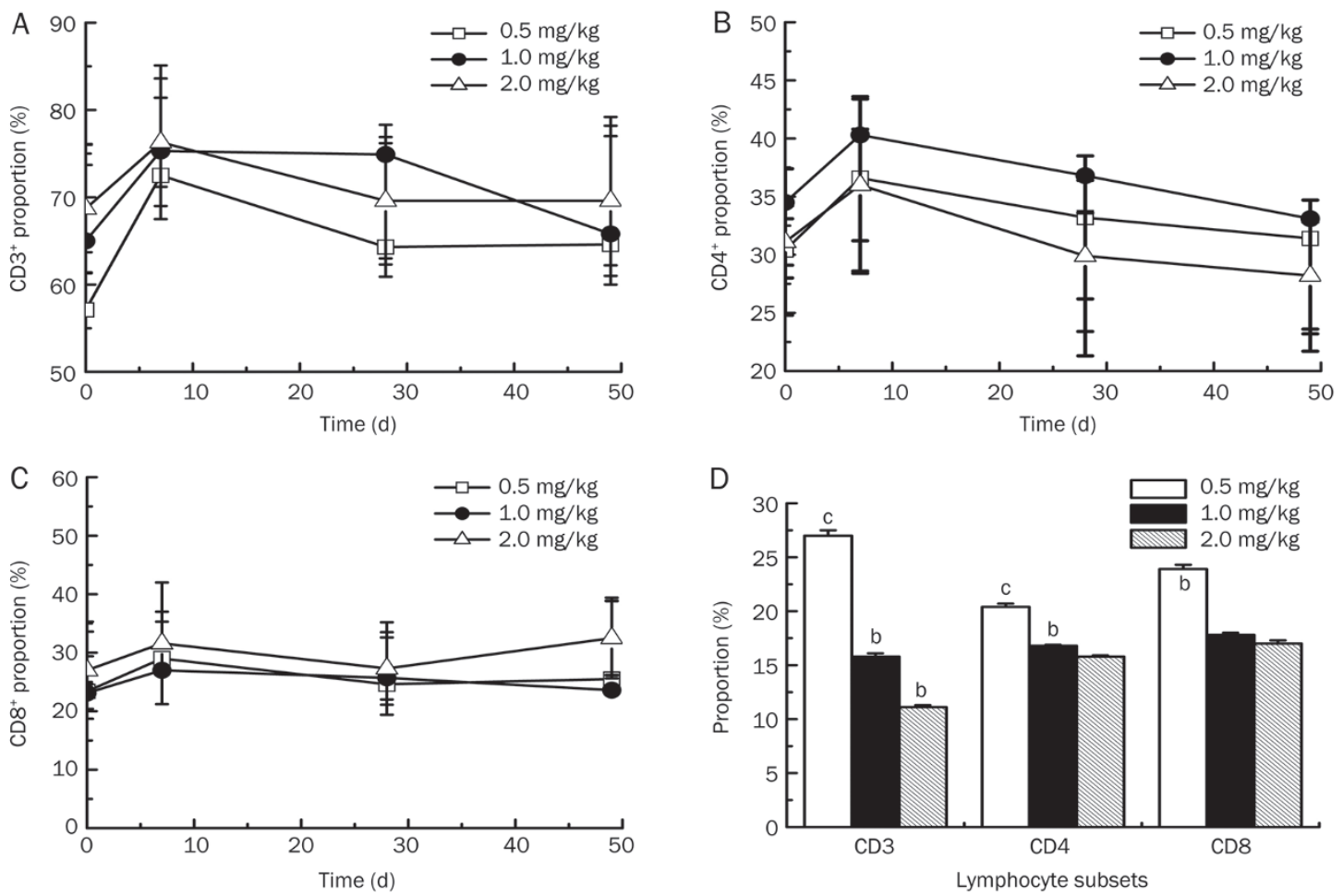

Figure 3. Mean proportion of T cell subsets $\left[\mathrm{CD}^{+}(\mathrm{A}), \mathrm{CD}^{+}(\mathrm{B})\right.$, and $\left.\mathrm{CD} 8^{+}(\mathrm{C})\right]$ before and after a single-dose subcutaneous injection of 0.5 , 1.0, and $2.0 \mathrm{mg} / \mathrm{kg}$ of CMAB001 in healthy volunteers. The increased degrees of T cell subsets on $\mathrm{d} 7$ after injection are compared with the baseline level (D). ${ }^{\mathrm{b}} P<0.05,{ }^{\mathrm{c}} P<0.01 \mathrm{vs}$ baseline level. Data are expressed as the mean \pm SD. $n=8$.
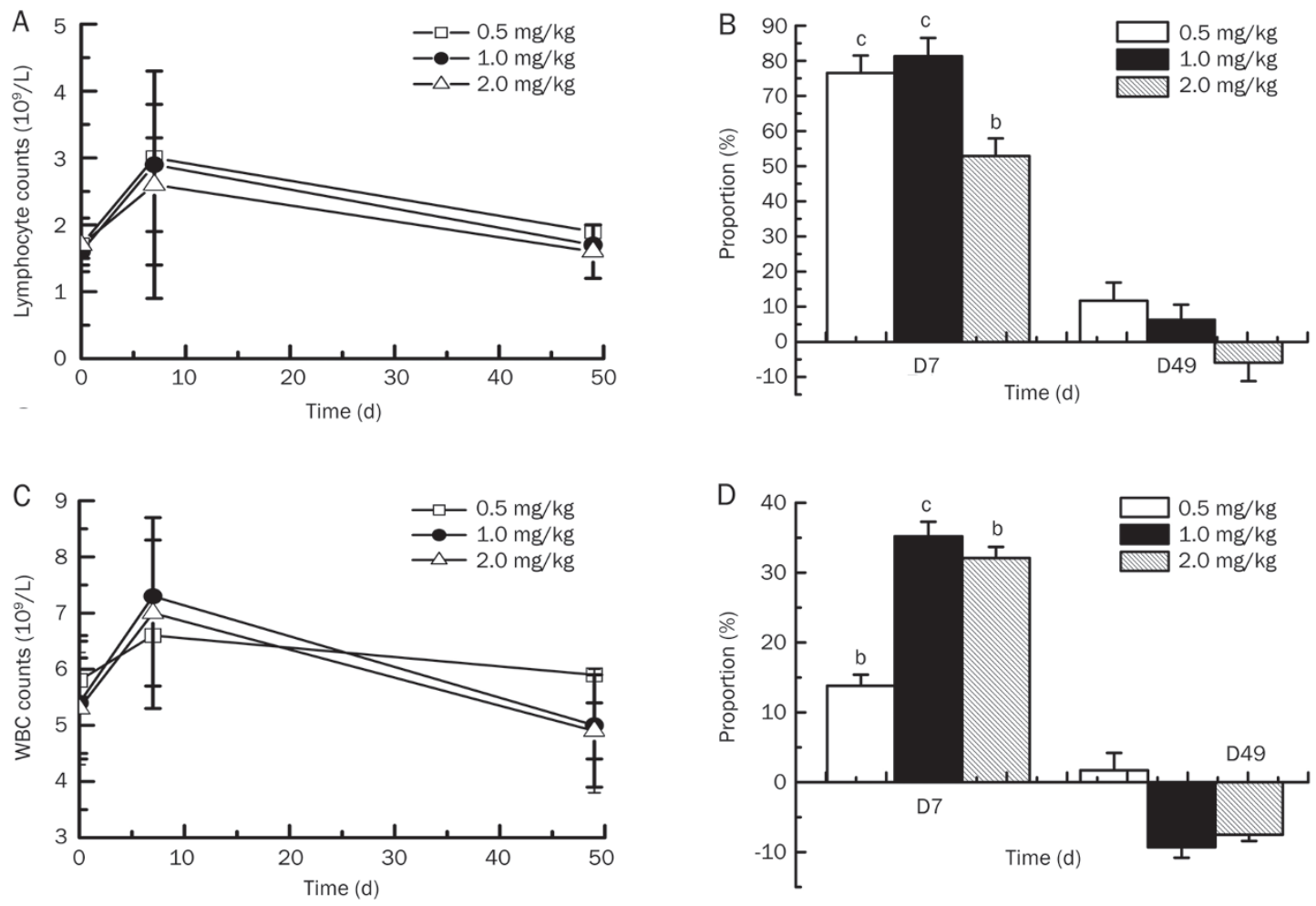

Figure 4. Mean absolute counts of lymphocytes (A) and white blood cells (WBC) (C) before and after a single-dose subcutaneous injection of 0.5 , 1.0, and $2.0 \mathrm{mg} / \mathrm{kg}$ of CMAB001. The increased levels of lymphocytes (B) and white blood cells (D) on d 7 and $\mathrm{d} 49$ after injections are compared with the baseline level. ${ }^{\mathrm{b}} P<0.05,{ }^{\mathrm{C}} P<0.01$ vs baseline level. Data are expressed as the mean $\pm \mathrm{SD} . n=8$. 


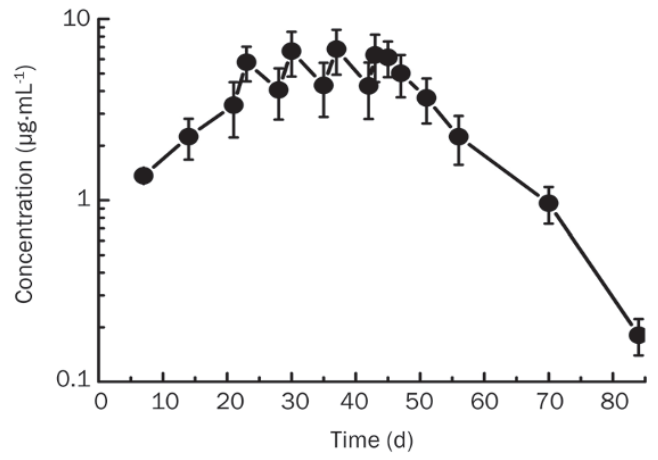

Figure 5. Logarithmic mean concentration-time curve of CMAB001 in psoriatic patients after weekly, consecutive subcutaneous injections for seven weeks at a dose of $1.0 \mathrm{mg} / \mathrm{kg}$. Data are expressed as the mean \pm SD. $n=10$.

Table 3. Steady-state pharmacokinetic parameters of CMABO01 following multiple dose subcutaneous administration of $1.0 \mathrm{mg} / \mathrm{kg}$ in patients with chronic plaque psoriasis $(n=10)$. $\mathrm{AUC}_{\mathrm{ss}}$, represents observed $\mathrm{AUC}_{0-z}$ after the last dose at steady-state.

\begin{tabular}{lcrrrrr}
\hline $\begin{array}{l}\text { Para- } \\
\text { meters }\end{array}$ & $\begin{array}{c}C_{\operatorname{minss}} \\
\left(\mu \mathrm{g} \cdot \mathrm{mL}^{-1}\right)\end{array}$ & $\begin{array}{c}C_{\operatorname{maxss}} \\
\left(\mu \mathrm{g} \cdot \mathrm{mL}^{-1}\right)\end{array}$ & $\begin{array}{c}C_{\text {avg }} \\
\left(\mu \mathrm{g} \cdot \mathrm{mL}^{-1}\right)\end{array}$ & $\begin{array}{c}\mathrm{AUC}_{\mathrm{ss}} \\
\left(\mathrm{d} \cdot \mu \mathrm{g} \cdot \mathrm{mL}^{-1}\right)\end{array}$ & $\begin{array}{r}\text { Fluctua- } \\
\text { tion (\%) }\end{array}$ & $\begin{array}{c}\text { Accumula- } \\
\text { tion_index }\end{array}$ \\
\hline 1 & 7.488 & 10.984 & 8.685 & 60.797 & 40.25 & 2.09 \\
2 & 5.025 & 6.911 & 5.976 & 41.835 & 31.55 & 2.14 \\
3 & 5.245 & 7.361 & 6.381 & 44.667 & 33.16 & 2.26 \\
4 & 2.902 & 5.106 & 4.350 & 30.447 & 50.67 & 2.29 \\
5 & 3.019 & 4.973 & 4.258 & 29.804 & 45.90 & 2.18 \\
6 & 3.957 & 5.961 & 5.098 & 35.683 & 39.31 & 2.34 \\
7 & 3.114 & 5.362 & 4.649 & 32.540 & 48.36 & 2.03 \\
8 & 2.835 & 4.667 & 3.908 & 27.357 & 46.86 & 2.25 \\
9 & 4.091 & 5.814 & 5.043 & 35.300 & 34.16 & 2.29 \\
10 & 5.086 & 6.722 & 5.854 & 40.977 & 27.93 & 2.19 \\
mean & 4.276 & 6.386 & 5.420 & 37.941 & 39.82 & 2.21 \\
SD & 1.472 & 1.845 & 1.403 & 9.819 & 7.91 & 0.10 \\
\hline
\end{tabular}

concentration level was achieved following 7 weekly doses based on the similarity of peak concentrations on weeks 4,5 , 6 , and 7. The mean $( \pm \mathrm{SD}) C_{\max s s}$ and $C_{\text {min ss }}$ were $(6.386 \pm 1.845)$ and $(4.276 \pm 1.472) \mu \mathrm{g} / \mathrm{mL}$, respectively. The mean $( \pm \mathrm{SD})$ fluctuation $\%$ and accumulation index at the steady state were $39.82 \% \pm 7.91 \%$ and $2.21 \pm 0.1$, respectively. The fluctuation $\%$ among patients was lower than anticipated. As the administration interval was $7 \mathrm{~d}$, which is slightly shorter than the half-life $(8 \mathrm{~d})$ of the drug, the accumulation index was lower, suggesting that no systemic accumulation would appear upon repeated treatments with $1.0 \mathrm{mg} / \mathrm{kg}$ weekly in psoriatic patients. The mean $( \pm S D) t_{1 / 2}$ and MRT were $8.03 \pm 0.48$ $\mathrm{d}$ and $12.84 \pm 0.78 \mathrm{~d}$, respectively. After multiple injections of CMAB001, the mean $( \pm \mathrm{SD}) \mathrm{Cl}$ was $(27.7 \pm 6.0) \mathrm{mL} \cdot \mathrm{d}^{-1} \cdot \mathrm{kg}^{-1}$. The mean $( \pm \mathrm{SD}) V_{\mathrm{ss}}$ was $(322.2 \pm 76.6) \mathrm{mL} / \mathrm{kg}$.

We also compared the pharmacokinetics of CMAB001 between healthy volunteers and psoriatic patients (Table 5). Compared with a single injection at a dose of $1.0 \mathrm{mg} / \mathrm{kg}$ in healthy volunteers, no significant difference was found in $V_{\mathrm{ss}}$ $(P=0.719$. Student's $t$-test) after multiple injections in psoriatic patients. However, significant differences were found in $t_{1 / 2}, C_{\max }$ and $\mathrm{Cl}$ between the two groups $(P<0.001$. Student's $t$-test).

\section{Lymphocyte subset proportion in multiple-dose group of psoriatic patients}

The mean proportion of $\mathrm{CD}^{+}, \mathrm{CD} 4^{+}, \mathrm{CD} 8^{+} \mathrm{T}$ cell subsets and the absolute value of white blood cells and lymphocyte cells were also measured in the multiple-dose study. The results showed that the absolute value of white blood cells increased by approximately $60 \%$ from the baseline level (data not shown) and then returned to baseline levels after discontinuation of CMAB001 treatment. $\mathrm{CD}^{+}$and $\mathrm{CD} 8^{+} \mathrm{T}$-cell subsets increased sharply during the treatment period and decreased slowly after the treatment ended (Figure 6). The largest increase in $\mathrm{CD}^{+}$and $\mathrm{CD} 8^{+} \mathrm{T}$-cell subsets was found on $\mathrm{d} 28$ after the first injection, while the largest increase in $\mathrm{CD} 4^{+} \mathrm{T}$-cell

Table 4. Pharmcokinetic parameters of CMAB001 after multiple-dose infusions of $1.0 \mathrm{mg} / \mathrm{kg}$ in patients with chronic plaque psoriasis ( $n=10$ ). MRT, mean retention time.

\begin{tabular}{|c|c|c|c|c|c|c|c|c|}
\hline Parameters & $\begin{array}{c}\mathrm{AUC}_{0-z} \\
\left(\mathrm{~d} \cdot \mu \mathrm{g} \cdot \mathrm{mL}^{-1}\right)\end{array}$ & $\begin{array}{c}\mathrm{AUC}_{0-\infty} \\
\left(\mathrm{d} \cdot \mu \mathrm{g} \cdot \mathrm{mL}^{-1}\right)\end{array}$ & $\begin{array}{l}\text { MRT } \\
\text { (d) }\end{array}$ & $\begin{array}{c}\mathrm{Cl}_{\mathrm{ss}} \\
\left(\mathrm{mL} \cdot \mathrm{d}^{-1} \cdot \mathrm{kg}^{-1}\right)\end{array}$ & $\begin{array}{c}V_{\mathrm{ss}} \\
\left(\mathrm{mL} \cdot \mathrm{kg}^{-1}\right)\end{array}$ & $\begin{array}{l}t_{1 / 2} \\
(d)\end{array}$ & $\begin{array}{c}C_{\max } \\
\left(\mu \mathrm{g} \cdot \mathrm{mL}^{-1}\right)\end{array}$ & $\begin{array}{l}T_{\max } \\
\text { (d) }\end{array}$ \\
\hline 1 & 133.96 & 136.53 & 12.01 & 16.4 & 177.4 & 7.48 & 10.984 & 7.48 \\
\hline 2 & 94.59 & 96.66 & 12.49 & 23.9 & 265.6 & 7.70 & 6.911 & 7.70 \\
\hline 3 & 106.13 & 108.95 & 13.42 & 22.4 & 267.6 & 8.29 & 7.361 & 8.29 \\
\hline 4 & 68.11 & 70.28 & 12.52 & 32.8 & 400.7 & 8.46 & 5.106 & 8.46 \\
\hline 7 & 73.54 & 74.70 & 12.45 & 30.7 & 317.2 & 7.15 & 5.362 & 7.15 \\
\hline 8 & 59.60 & 61.40 & 12.02 & 36.6 & 434.3 & 8.23 & 4.667 & 8.23 \\
\hline 9 & 83.66 & 86.06 & 13.40 & 28.3 & 345.3 & 8.45 & 5.814 & 8.45 \\
\hline 10 & 101.40 & 103.35 & 13.97 & 24.4 & 279.9 & 7.95 & 6.722 & 7.95 \\
\hline mean & 87.41 & 89.51 & 12.84 & 27.7 & 322.2 & 8.03 & 6.386 & 8.03 \\
\hline
\end{tabular}


Table 5. Comparison of pharmacokinetic parameters of CMAB001 at a dose of $1.0 \mathrm{mg} / \mathrm{kg}$ in healthy adult volunteers and patients with chronic plaque psoriasis.

\begin{tabular}{lccc}
\hline Parameters & $\begin{array}{c}\text { Healthy volunteers } \\
(1.0 \mathrm{mg} / \mathrm{kg} \times 1) \\
n=8\end{array}$ & $\begin{array}{c}\text { Psoriasis patients } \\
(1.0 \mathrm{mg} / \mathrm{kg} \times 4) \\
n=10\end{array}$ & $P$ value \\
& $3.006 \pm 0.402$ & $6.386 \pm 1.845$ & $<0.001$ (Paired $t$-test) \\
$C_{\max }\left(\mu g \cdot \mathrm{mL}^{-1}\right)$ & $5.81 \pm 0.41$ & $8.03 \pm 0.48$ & $<0.001$ (Paired $t$-test) \\
$t_{1 / 2}(\mathrm{~d})$ & $39.8 \pm 3.5$ & $27.7 \pm 6.0$ & $<0.001$ (Paired $t$-test) \\
$\mathrm{Cl}_{\mathrm{ss}}\left(\mathrm{mL} \cdot \mathrm{d}^{-1} \cdot \mathrm{kg}^{-1}\right)$ & $333.0 \pm 39.0$ & $322.2 \pm 76.6$ & 0.719 (Paired $t$-test) \\
$V_{\mathrm{ss}}\left(\mathrm{mL} \cdot \mathrm{kg}^{-1}\right)$ & $8.03 \pm 0.66$ & $12.84 \pm 0.78$ & $<0.001$ (Paired $t$-test) \\
$M R T(d)$ & & & \\
\hline
\end{tabular}

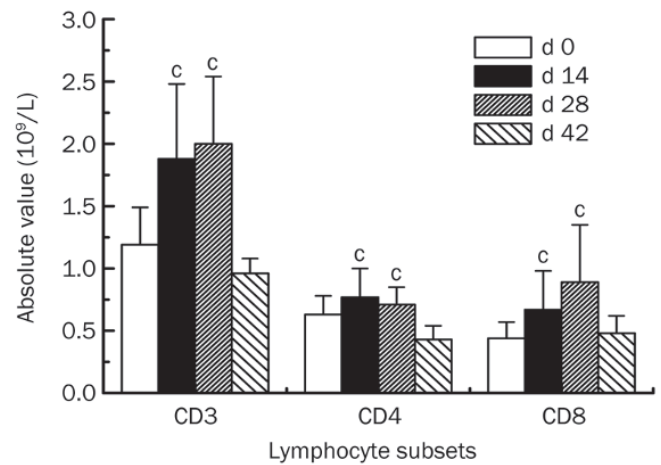

Figure 6. Absolute counts of T-cell subsets before and after consecutive subcutaneous injections of CMABO01 weekly for 7 weeks in psoriatic patients detected on d $0,14,28$, and 42 after the first administration. ${ }^{c} P<0.01$ vs baseline level. Data are expressed as the mean \pm SD. $n=10$.

subset was observed on d 14 after the first injection. These changes were clearly statistically significant. An outstanding change $(202.3 \%)$ was found in the $\mathrm{CD} 8^{+} \mathrm{T}$-cell subset, which increased from baseline level $\left(0.44 \times 10^{9} / \mathrm{L}\right)$ to the highest level $\left(0.89 \times 10^{9} / \mathrm{L}\right)(P<0.001$. Paired $t$-test $)$.

\section{Tolerability}

Tolerability of CMAB001 was carefully monitored during the treatment and follow-up period by collection of all adverse events (AEs) and serious adverse events (SAEs). All events were summarized and any relationship to the test drug was reported. There appeared to be a dose-related increase in the occurrence of AEs in the single-dose study. In the $2.0 \mathrm{mg} / \mathrm{kg}$ group, all subjects experienced one or two AEs, but in the 0.5 and $1.0 \mathrm{mg} / \mathrm{kg}$ groups, incidence rates were only $25 \%$ and $62.5 \%$, respectively. These AEs included common cold, fever, dizziness, and cough, all of which were considered to be related to the medication in this study but were classified as minor to moderate in severity and resolved without treatment. There were no significant clinical changes in laboratory parameters, vital signs or results of electrocardiogram examinations. In the multiple-dose study, nearly half of all AEs were first-dose effects; most of AEs occurred 2 or $4 \mathrm{~h}$ after the first dose administration. Other AEs were sleepiness, cough, injection-site reaction and sore throat. All of AEs were minor in severity, and disappeared without treatment. No SAEs were experienced during the entire study period. No patients withdrew from the study due to AEs.

\section{Primary efficacy in the multiple-dose group}

In a phase I trial, the main tasks are to evaluate PD, PK, and the primary safety profile of the test drug. Therefore, there was little information about the clinical response from the phase I study. In our multiple-dose study, we observed therapeutic efficacy in psoriatic patients. The Psoriasis Area and Severity Index (PASI) is the most commonly used method to evaluate disease severity. In part two, after 7 weeks of CMAB001 treatment, 20\%, 20\%, and 30\% of patients achieved PASI90 (at least a 90\% reduction in PASI score from baseline), PASI75, and PASI50, respectively. The total efficacy rate was $70 \%$. However, $20 \%$ of patients experienced a rebound in psoriasis symptoms 2 weeks after CMAB001 discontinuation.

\section{Anti-antibody and neutralizing anti-antibody antibody}

No anti-antibody antibodies or neutralizing anti-antibody antibodies were detected.

\section{Discussion}

Antibodies to LFA-1 or its ligands that interfere with the LFA-1/ICAM-1 adhesion mechanism attenuate a broad range of T-cell-mediated reactions in vitro and in animal models ${ }^{[14-16]}$. In the phase I clinical study, we aimed to investigate the safety, PK, and PD parameters of CMAB001 and expected to select an appropriate dose and schedule for further phase II studies. Specifically, it was the first study in humans and was conducted in the Chinese.

In these two studies, CMAB001 exhibited a predictable PK profile and was well tolerated in both healthy volunteers and patients. No SAEs occurred after injection, and no subjects withdrew from the study because of AEs. Some drug-related, treatment-emergent AEs were observed in the single-dose studies but were minor in severity and did not require treatment. In the multiple-dose study, no serious clinical or laboratory events were observed during the course of the study. In summary, following multiple injections of a dose of $1.0 \mathrm{mg} / \mathrm{kg}$ weekly for 4 weeks, the patients were generally safe. How- 
ever, in April 2009, efalizumab was withdrawn from the market after reports of an association between long-term therapy and the development of PML emerged ${ }^{[17]}$. This result raises cause for concern that CMAB001 will also increase the risk for PML. When compared with efalizumab, CMAB001 binds a different epitope on CD11a. CMAB001 has been studied in a phase II randomized, double-blind, placebo-controlled trial involving 240 Chinese patients with moderate to severe plaque psoriasis (data not shown). The patients were followed for 12 weeks. Consistent with the results of all pivotal studies prior to the approval of efalizumab, CMAB001 was generally well tolerated, no cases of PML or infections predominantly associated with immunosuppression were recognized, and there were no reports of death. The absence of PML in CMAB001 clinical trials may be attributable to a special population or the different epitopes recognized by CMAB001 and efalizumab. Nonetheless, we did not have enough evidence to rule out the possibility of PML risks of CMAB001. Additional efforts are required to investigate its potential for immunosuppression, JC-virus reactivation, and the development of PML with further treatment. Considering every newly diagnosed or suspected cases of PML, we should also take into account intensive risk-management initiatives. Recently, preliminary evidence for the treatment of other autoimmune diseases (Crohn's disease, for example) with efalizumab has attracted wide interest in these therapeutic areas ${ }^{[18]}$. This highlights the urgent need for greater awareness of and research into the screening, diagnosis and treatment of this potentially fatal disease in patients undergoing immunosuppressive therapy for chronic inflammatory disorders.

Data demonstrated that the subcutaneous injection of CMAB001 exhibited a nonlinear pharmacokinetic profile over the doses of $0.5-2.0 \mathrm{mg} / \mathrm{kg}$ in the single-dose study (Figure 2 and Table 3), which may be explained by the saturation of the specific binding to its cell surface receptor, CD11 ${ }^{[19,20]}$. To understand the pharmacokinetic behavior of CMAB001 at different doses, we selected different approaches to assess our pharmacokinetic parameters. Linear regression was selected for $C_{\max }$ analysis; polynomial regression for dose-normalized $\mathrm{AUC}_{0-\mathrm{z}}$ analysis; and graphical display scatter chart for $t_{1 / 2}$ and $\mathrm{Cl}$ was used to support our non-linear PK profile conclusion. Our data showed that there was a linear relationship between $C_{\max }$ and dosage over the range of $0.5-2.0 \mathrm{mg} / \mathrm{kg}$ (Figure $\left.2 \mathrm{~A}, R^{2}=0.937\right)$. There was a nonlinear behavior in dosenormalized $\mathrm{AUC}_{0-\mathrm{z}}$ (Figure $2 \mathrm{~B}, R^{2}=0.854$ ), $t_{1 / 2}$ (Figure $2 \mathrm{C}$ ), and $\mathrm{Cl}$ (Figure 2D). The same results were demonstrated in Table 2. The dose-normalized $\mathrm{AUC}_{0-\mathrm{z}}$ were significantly different among the groups, whereas the dose-normalized $C_{\max }$ was not. $t_{1 / 2}$ and MRT presented gradually extended tendency, while the $\mathrm{Cl}$ demonstrated a decreasing trend over the dose range of $0.5-2.0 \mathrm{mg} / \mathrm{kg}$. The data may be interpreted as the $t_{1 / 2}$ of the combination of two clearance mechanisms: first-order Fcmediated clearance and zero-mediated CD11a receptor-mediated clearance of CMAB001. In our study, the $V_{d}$ value was similar among the three single-dose groups and the multipledose group, indicating that CMAB001 was distributed primar- ily through the entire body fluid system. These results support the current body weight-adjusted dosing strategy. Negligible accumulation of CMAB001 was observed after multiple dosing. Because of nonlinear clearance, extended half-life, and extended mean retention time, more attention should be paid to the detection of potential accumulation toxicity in future trials.

In psoriasis, the $\mathrm{CD}^{+} \mathrm{T}$-cell subset seems to be important mainly during the early phase of plaque development ${ }^{[21,22]}$, but the $\mathrm{CD}^{+} \mathrm{T}$-cell subset represents the largest population in the epidermis and dermis in active psoriasis ${ }^{[23]}$, and thus, the increase in the $\mathrm{CD} 4^{+} \mathrm{T}$-cell subset was not the key element in selecting the dosage for the multiple-dose study. In our study, the greatest increase in absolute lymphocyte and white blood cell counts occurred in the $1.0 \mathrm{mg} / \mathrm{kg}$ group. Simultaneously considering pharmacokinetics, pharmacodynamics, safety profile, and referring to the previous trial, we selected the 1.0 $\mathrm{mg} / \mathrm{kg}$ dose for the multiple-dose study.

In clinical studies of efalizumab, the results showed that efalizumab can induce a marked but reversible increase in peripheral lymphocytes in psoriasis patients ${ }^{[23-25]}$. Both populations of $\mathrm{CD}^{+}$and $\mathrm{CD}^{+} \mathrm{T}$ cells in the peripheral blood increased, with the largest increase observed in memory CD8 ${ }^{+}$ $\mathrm{T}$ cells. A marked increase in lymphocyte count was present by d 14 of efalizumab treatment ${ }^{[23,24]}$. In our study, similar results were obtained. In our phase I trial, the results showed that subcutaneous administration of CMAB001 induced a significant but reversible increase in peripheral white blood cell and lymphocyte cell counts. In the multiple-dose study, the increases in $\mathrm{CD}^{+}$and $\mathrm{CD}^{+} \mathrm{T}$ cells were more predominate. Increases in leukocyte counts and lymphocyte subsets are due to the reversal of leukocyte adhesion to the blood vessel walls $^{[8,16,26,27]}$, which can be considered as predominantly accumulating in the peripheral blood under CMAB001 treatment of psoriasis. The blockade of percutaneous entry of the highly disease-relevant memory $\mathrm{CD}^{+}$and $\mathrm{CD}^{+} \mathrm{T}$-cell populations is the therapeutic mechanism of anti-CD11a antibodies ${ }^{[23]}$; our results are consistent with this mechanism. These increases in the subset levels have clinical significance. The results show that the absolute count increases in circulating lymphocytes are unrelated to AE. However, further evaluation of the safety and efficacy of CMAB001 should be investigated in the future, pivotal phase III clinical trials.

\section{Acknowledgements}

This project was supported by the National Natural Science Foundation of China, Shanghai Commission of Science \& Technology, Ministry of Science and Technology of China (973 \& 863 Program Projects), National Key projects for New Drug Development and Manufacture, Shanghai Pudong Commission of Science \& Technology and Shanghai Leading Academic Discipline Project (B905). Special thanks to the study subjects and referring physicians for their participation in this study.

\section{Author contribution}

Ya-jun GUO, Hao WANG, and Jing LI designed the research 
study; Xian-ping LI, Jing LI, Bo ZHOU, Bo-hua LI, Heng YAN, Wei-zhu QIAN, Sheng HOU, and Fei HAO performed the research; Hao WANG contributed new analytical tools and reagents; Xian-ping LI and Jing LI analyzed the data; and Ya-jun GUO, Xian-ping LI, Jing LI, and Bo-hua LI wrote the manuscript.

\section{References}

1 Li S, Wang $\mathrm{H}$, Peng B, Zhang M, Zhang D, Hou S, et al. Efalizumab binding to the LFA-1 $\alpha \mathrm{L}$ I domain blocks ICAM-1 binding via steric hindrance. Proc Natl Acad Sci U S A 2009; 106: 4349-54.

2 Mehlis SL, Gordon KB. The immunology of psoriasis and biologic immunotherapy. J Am Acad Dermatol 2003; 49: S44-50.

3 Jullien D, Prinz JC, Langley RG, Caro I, Dummer W, Joshi A, et al. T-cell modulation for the treatment of chronic plaque psoriasis with efalizumab (Raptiva): mechanisms of action. Dermatology 2004; 208: 297-306.

4 Lee KH, Dinner AR, Tu C, Campi G, Raychaudhuri S, Varma R, et al. The immunological synapse balances $T$ cell receptor signaling and degradation. Science 2003; 302: 1218-22.

5 Gottlieb A, Krueger JG, Bright R, Ling M, Lebwohl M, Kang S, et al. Effects of administration of a single dose of a humanized monoclonal antibody to CD11a on the immunobiology and clinical activity of psoriasis. J Am Acad Dermatol 2000; 42: 428-35.

6 Papp K, Bissonnette R, Krueger JG, Carey W, Gratton D, Gulliver WP, et al. The treatment of moderate to severe psoriasis with a new antiCD11a monoclonal antibody. J Am Acad Dermatol 2001; 45: 665-74.

7 Dedrick RL, Bodary S, Garovoy MR. Adhesion molecules as therapeutic targets to autoimmune diseases and transplant refection. Expert Opin Biol Ther 2003; 3: 85-95.

8 Mortensen DL, Walicke PA, Wang X, Kwon P, Kuebler P, Gottlieb AB, et al. Pharmacokinetics and pharmacodynamics of multiple weekly subcutaneous efalizumab doses in patients with plaque psoriasis. J Clin Pharmacol 2005; 45: 286-98.

9 Gottlieb AB, Krueger JG, Wittkowski K, Dedrick R, Walicke PA, Garovoy $M$. Psoriasis as a model for T cell-mediated disease: immunobiologic and clinical effects with multiple doses of efalizumab, an anti-CD11a antibody. Arch Dermatol 2002; 138: 591-600.

10 Dedrick RL, Walicke P, Garovoy M. Anti-adhesion antibodies efalizumab, a humanized anti-CD11a monoclonal antibody. Transpl Immunol 2002; 9: 181-6.

11 Singri P, West DP, Gordon KB. Biologic therapy for psoriasis: the new therapeutic frontier. Arch Dermatol 2002; 138: 657-63.

12 Gottlieb AB, Miller B, Lowe N, Shapiro W, Hudson C, Bright R, et al. Subcutaneously administered efalizumab (anti-CD11a) improves signs and symptoms of moderate to severe plaque psoriasis. J Cutan Med Surg 2003; 7: 198-207.

13 Springer TA. Adhesion receptors of the immune system. Nature 1990; 346: 425-34.
14 Kuypers TW, Roos D. Leukocyte membrane adhesion proteins LFA-1, CR3 and p150, 95: a review of functional and regulatory aspects. Res Immunol 1989; 140: 461-86.

15 Gordon EJ, Myers KJ, Dougherty JP, Rosen H, Ron Y. Both efalizumab (LFA-1) and anti-CD11b (MAC-1) therapy delay the onset and diminish the severity of experimental autoimmune encephalomyelitis. J Neuroimmunol 1995; 62: 153-60.

16 Coffey GP, Stefanich E, Palmieri S, Eckert R, Padilla-Eagar J, Fielder PJ, et al. In vitro internalization, intercellular transport, and clearance of an anti-CD11a antibody (Raptiva) by human T-cells. J Pharmacol Exp Ther 2004; 310: 896-904.

17 Berger JR, Houff SA, Major EO. Monoclonal antibodies and progressive multifocal leukoencephalopathy. MAbs 2009; 1: 583-9.

18 James DG, Seo DH, Chen J, Vemulapalli C, Stone CD. Efalizumab, a human monoclonal anti-CD11a antibody, in the treatment of moderate to severe Crohn's disease: An open-label pilot study. Dig Dis Sci 2011; 56: 1806-10.

19 Homepage of the Food and Drug Administration. Available from: http://www.fda.gov/ohrms/ac/03/briefing/3983B1_01_GenentechRaptiva.pdf.

20 Coffey GP, Fox JA, Pippig S, Palmieri S, Reitz B, Gonzales M, et al. Tissue distribution and receptor-mediated clearance of anti-CD11a antibody in mice. Drug Metab Dispos 2005; 33: 623-9.

21 Langewouters AM, van Erp PE, de Jong EM, van de Kerkhof PC. Lymphocyte subsets in peripheral blood of patients with moderate-tosevere versus mild plaque psoriasis. Arch Dermatol Res 2008; 300: 107-13.

22 Joshi A, Bauer R, Kuebler P, White M, Leddy C, Comptom P, et al. An overview of the pharmacokinetics and pharmacodynamics of efalizumab: a monoclonal antibody appoved for use in psoriasis. J Clin Pharmacol 2006; 46: 10-20.

23 Vugmeyster Y, Kikuchi T, Lowes MA, Chamian F, Kagen M, Gilleaudeau $\mathrm{P}$, et al. Efalizumab (anti-CD11a)-induced increase in peripheral blood leukocytes in psoriasis patients is preferentially mediated by altered trafficking of memory CD8+ T cells into lesional skin. Clin Immunol 2004; 113: 38-46.

24 Shear NH, Langley RG, Ho V. Efalizumab, a reversible T-cell modulator for psoriasis. J Cutan Med Surg 2006; 9: 4-9.

25 Harper EG, Simpson EL, Takiquchi RH, Boyd MD, Kurtz SE, Bakke AC, et al. Efalizumab therapy for Atopic Dermatitis causes marked increases in circulating effector memory CD4+ T cells that express cutaneous lymphocyte antigen. J Invest Dermatol 2008; 128: 117381.

26 Krueger JG. The immunologic basis for the treatment of psoriasis with new biologic agents. J Am Acad Dermatol 2002; 46: 1-23.

27 Bonnekoh B, Malykh Y, Bockelmann R, Bartsch S, Pommer AJ, Gollnick $\mathrm{H}$. Profiling lymphocyte subpopulations in peripheral blood under efalizumab treatment of psoriasis by multi epitope ligand cartography (MELC) robot microscopy. Eur J Dermatol 2006; 16: 623-35. 